\title{
RELEVANSI HUKUMAN CAMBUK SEBAGAI SALAH SATU BENTUK PEMIDANAAN DALAM PEMBAHARUAN HUKUM PIDANA*
}

\author{
Madiasa Ablisar \\ Fakultas Hukum Universitas Sumatera Utara \\ E-mail: ablisar@yahoo.co.id
}

\begin{abstract}
The use of Islamic law as the material for criminal law reformation is one of the main characteristics of Pancasila law state which guarantees the freedom of religion. The existing applicable law should be consistent with the Indonesian society legal ideals, the values of Islamic law must be reflected in the national law as the materialization of legal ideals. Canings is one of the punishment types prescribed in the Qur'an and Sunnah. Article 2 of RKUHP contains material legality principle approves the existing law in the community/society or adat criminal law in order to respect the diversities/ plurality law in Indonesia. Accordingly, the regulation of criminal act and criminal sanction are mandated to the development of jurisprudence and regional regulation.
\end{abstract}

Keywords: Canings, criminal law reform, Islamic law,

\begin{abstract}
Abstrak
Pemanfaatan hukum Islam sebagai bahan pembaharuan hukum pidana merupakan salah satu ciri pokok dari Negara hukum Pancasila yang menjami adanya kebebasan beragama. Hukum yang berlaku harus konsisten pada cita hukum masyarakat Indonesia, nilai-nilai hukum agama Islam harus tercermin dalam hukum nasional sebagai perwujudan cita hukum. Hukuman cambuk merupakan salah satu jenis hukuman yang ditentukan dalam al-Qur'an dan sunnah. Pasal 2 RKUHP mengandung asas legalitas materiel yang secara implisit mengakui hukum yang hidup dalam masyarakat atau hukum pidana adat, untuk menghormati keanekaragaman hukum yang hidup di Indonesia sebaiknya pengaturan tindak pidana dan sanksi pidana diserahkan pada perkembangan yurisprudensi dan Peraturan Daerah.
\end{abstract}

Kata kunci: hukuman cambuk, pembaharuan hukum pidana, hukum Islam

\section{Pendahuluan}

Konsep Rancangan KUHP (selanjutnya disingkat RKHUP) tahun 1968 dalam Bab V Pasal 43 dan Konsep Rancangan KUHP Tahun 1972 dalam Bab V Pasal 43 menentukan bahwa Pengenaan Kewajiban Agama merupakan salah satu jenis Pidana Tambahan. Ditentukannya Pengenaan Kewajiban Agama sebagai salah satu jenis pidana tambahan terlihat adanya kecenderungan untuk menjadikan agama sebagai salah satu sumber untuk penyusunan Konsep RKUHP, meskipun tidak dijelaskan bentuk-bentuk pemenuhan kewajiban agama yang dapat dijatuhkan oleh Hakim. Pasal 78 Konsep RKUHP tahun 1968

- Artikel ini merupakan sebahagian dari bahan Disertasi (S3) dengan judul "Pembaharuan Hukum Pidana: Studi Hukuman Cambuk di Aceh" pada Program Studi Doktor (S3) Ilmu Hukum USU pada tahun 2010. dan Pasal 48 Konsep RKUHP tahun 1972 dinyatakan Hakim dapat menjatuhkan kewajiban agama yang dianutnya sebagai permohonan ampun kepada Tuhan Yang Maha Esa.

Sejak Konsep RKUHP mulai tahun 1982/ 1983 sampai Konsep RKUHP terakhir tahun 2012, jenis pidana tambahan Pengenaan Kewajiban Agama tidak lagi dijadikan sebagai salah satu jenis pidana. Dihilangkannya pemenuhan kewajiban agama yang sebelumnya dicantumkan dalam Konsep Rancangan KUHP dapat ditafsirkan sebagai kemunduran politik perancangan jika ditinjau dari prespektif agama dalam pembaharuan hukum pidana Nasional dan bertentangan dengan kebijakan pemerintah dalam rangka pembangunan hukum Nasional yang mengamanatkan bahwa pembangunan hukum Nasional diupayakan memanfaatkan tiga sitem 
hukum, yaitu; sistem hukum adat, Islam dan Barat (Belanda) sebagai bahan baku. ${ }^{1}$

Eksistensi Syari'at Islam di Indonesia menjadi hukum positif hanya berkaitan dengan hukum privat, sedangkan yang berhubungan dengan hukum publik Islam sampai saat ini masih menjadi hukum yang dicita-citakan, upaya positifisasi Syari'at Islam nampaknya mengalami kejanggalan sesuatu yang bersifat publik keberlakuannya malah tidak dilegalisasi, tetapi berkaitan dengan masalah privat justru dijadikan hukum positif. ${ }^{2}$

Pelaksanaan Syari'at Islam di Aceh mendapat angin segar, lengsernya Soeharto yang digantikan oleh B.J. Habibi. B.J. Habibi memberikan respon terhadap keinginan masyarakat Aceh untuk melaksanakan Syari'at Islam dan menimbulkan semangat baru bagi isu-isu pelaksanaan Islam di Aceh dengan berlakunya Undang-undang (selanjutnya disingkan UU) Nomor $44 \mathrm{Ta}$ hun 1999 Tentang Pelaksanaan Keistimewaan Aceh (bidang agama, adat, pendidikan dan kebudayaan), yang dipertegas oleh UU Nomor 22 Tahun 1999 Tentang Otonomi Khusus. Selanjutnya dipertegas lagi dengan UU Nomor 18 Tahun 2001 Tentang Otonomi Khusus bagi Provinsi Daerah Istimewa Aceh sebagai Provinsi Nanggroe Aceh Darusalam, ${ }^{3}$ terakhir Undang-undang Nomor 11 Tahun 2006 Tentang Pemerintahan Aceh.

Bersamaan dengan lahirnya UU Nomor 14 Tahun 1999 daerah-daerah lain mengadopsi Syari'at Islam ke dalam Peraturan Daerah, pembuatan Perda dengan corak Syari'at Islam menjamur setelah proses reformasi yang bergulir sejak tahun 1999, secara legal formal pintu perdaisasi Syari'at Islam itu terbuka lebih lebar ketika konsep desentarisasi diakui dengan di-

Imam Syaukani, 2006, Rekontruksi Epistimologi Hukum Islam Indonesia Dan Relevansinya Bagi Pembangunan Hukum Nasional, Jakarta: PT Raja Grasindo Persada, hlm. 269.

2 Ibnu Hadjar, "Syariat Islam dan Hukum Positif di Indonesia", Al-Muwarid (Jurnal Hukum Islam), Edisi XVI Tahun 2006, Yokyakarta: Program Stusi Hukum Islam Fakultas Ilmu Agama Islam Universitas Islam Indonesia hlm. 10.

3 Yuni Saby, "Pelaksanaan Syari'at Islam di Aceh; Suatu Peluang dan Tantangan", Jurnal Kanun, 2002, Banda Aceh: Fakultas Hukum Universitas Syiah Kuala, hlm. 566-568. tetapkannya UU Nomor 22 tahun 1999 tentang Pemerintah Daerah, interprestasi otonomi yang luas berdasarkan UU tersebut diartikan oleh sebagian orang dengan mereinkarnasi indentitasindentitas lokal yang dirasa pernah diberangus oleh praktik sentralisasi. ${ }^{4}$

Pasal 125 UU Nomor 11 Tahun 2006, menentukan bahwa untuk melaksanakan Sya-ri'at Islam di Aceh diatur melalui Qanun. Qanun dipersamakan dengan Perda di daerah lain, tetapi isi Perda berbeda dengan Qanun. Qanun haruslah berlandaskan pada asas keislaman atau tidak bertentangan dengan Syari'at Islam. ${ }^{5}$ Qanun digunakan sebagai istilah untuk Peraturan Daerah Plus atau lebih tepatnya Peraturan Daerah yang menjadi peraturan pelaksana langsung untuk Undang-undang dalam rangka otonomi khusus di Provinsi Nanggroe Aceh Darussalam. ${ }^{6}$

Pemerintah Aceh telah mengesahkan beberapa Qanun untuk pelaksanaan Syari'at Islam dalam kehidupan masyarakat Aceh. Qanun tersebut diantaranya ada 3 (tiga) Qanun yang termasuk hukum pidana (Jinayah), yaitu; Qanun Nomor 12 Tahun 2003 Tentang Minuman Khamar dan sejenisnya, Qanun Nomor 13 Tahun 2003 Tentang Maisier (perjudian) dan Qanun Nomor 14 Tahun 2003 Tentang Khalwat (perbuatan mesum), (selanjutnya disebut Qanun Aceh).

Pasal 26 Qanun Nomor 12 Tahun 2003 menentukan bagi setiap orang yang mengonsumsi minuman khamar atau sejenisnya diancam dengan hukuman cambuk 40 (empat puluh) kali cambukan sebagai hukuman hudud. Pasal 23 Qanun Nomor 13 Tahun 2003 menentukan hukuman cambuk paling banyak 12 (dua belas) kali cambukan dan paling sedikit 6 (enam) kali cambukan bagi setiap orang yang melakukan per-

4 Deny Indrayana, “Konpleksitas Peraturan Daerah Bernuansa Syari'at Perspektif Hukum Tata Negara", Yustisia Jurnal Hukum, Edisi 81 September-Desember 2010, Surakarta: Fakutas Hukum Universitas Sebelas Maret, hlm. 95-96.

5 Jum Anggriani, "Kedudukan Qanun Dalam Sistem Pemerintah Daerah dan Mekanisme Pengawasannya", Jurnal Hukum, No. 3 Vol. 18 Juli 2011, Yokyakarta: Fakultas Hukum Universitas Islam Indonesia, hlm. 327.

6 Al-Yasa'Abubakar dan M. Daud Yoesoef, "Qanun Sebagai Pelaksana Otonomi Khusus di Provinsi Nanggroe Aceh Darussalam", Jurnal Legislasi Indonesia, Vol. 1 No. 3 November 2004, Jakarta: Direktorat Jenderal Perundang-undangan Departemen Hukum dan HAM RI, hlm. 21. 
buatan maisir (perjudian), sedangkan bagi setiap orang yang melakukan perbuatan Khalwat (perbuatan mesum) diancam dengan hukuman cambuk paling banyak 9 (sembilan) kali dan paling sedikit 3 (tiga) kali cambukan.

Perumusan sanksi pidana dalam Qanun Aceh dilakukan dengan sistem alternatif dan kumulatif, dengan menentukan batas minimal dan batas maksimal, yakni; hukuman cambuk maksimal 9 (Sembilan) kali cambukan dan minimal 3 (tiga) kali cambukan, dan hukuman denda maksimal Rp 10.000.000,- (sepuluh juta rupiah) dan minimal Rp. 2.000.000,- (dua juta rupiah). Bagi setiap orang yang memberikan fasilitas, membantu atau melindungi orang lain untuk melakukan perbuatan Khalwat (perbuatan mesum) dikenai hukuman secara kumulatif, maksimal 6 (enam) bulan kurungan dan minimal 2 (dua) bulan kurungan dan denda maksimal Rp. 15.000. 000,- (lima belas juta rupiah), minimal Rp. 5.000.000,- (lima tuja rupiah). ${ }^{7}$

Perumusan Qanun Aceh sebagaimana telah disebutkan diatas didasarkan pada Al-Qur'an dan hadis Nabi Saw; dengan berpegang pada penafsiran/pemahaman atas Al-Qur'an dan hadis Nabi Saw dengan tetap memakai ketentuan ketentuan lama atau pendapat mazhab-mazhab yang masih relevan serta berusahan untuk mencari dan merumuskan ketentuan baru yang lebih baik; dengan memperhatikan kebutuhan lokal masyarakat Aceh; dan dengan memperhatikan isu-isu hak asasi manusia dan Konvensi Menentang Penyiksaan dan perlakuan atau penghukuman lain yang kejam, tidak manusiawi atau merendahkan martabat manusia.

Pelasanaan hukuman Cambuk pertama kali di lakukan di Indonesia setelah masa kerajaan Islam Nusantara, pada tanggal 24 Juni 2005 di halaman mesjid Agung Bireun provinsi Aceh. Sejak tahun 2005 sampai dengan 2008, jumlah pelaku yang melanggar Qanun dan dijatuhkan sanksi hukuman cambuk sebanyak 275 orang. Pada tahun 2005 sebanyak 101 orang, tahun

Madiasa Ablisar, "Pemberlakuan Hukum Pidana Qanun Aceh”, Equality Jurnal Hukum, Volume 16, No. 2 Agustus 2011, Medan: Fakultas Hukum Universitas Sumatera Utara, hlm. 136.
2006 sebanyak 61 orang, tahun 2007 sebanyak 58 orang dan tahun 2008 sebanyak 55 orang. ${ }^{8}$

\section{Permasalahan}

Berdasarkan uraian diatas, permasalahan yang dibahas dalam tulisan ini adalah: Pertama, apakah relevansi hukuman cambuk dalam pembaharuan hukum pidana?; dan kedua, bagaimanakah pelaksanaan hukuman cambuk?.

\section{Metode Penelitian}

Menjawab permasalahan sebagaimana dirumuskan diatas, tipe penelitian yang digunakan adalah penelitian hukum normatif. Pendekatan masalah yang digunakan dalam penelitian ini adalah pendekatan perundang-undangan (Statute Aprroach) dilakukan dengan melakukan analisis terhadap bahan-bahan hukum yang berhubungan dengan permasalahan, pendekatan konseptual (Conceptual Approach) dilakukan dengan menelaah konsep-konsep dan doktrindoktrin hukum.

Sumber bahan hukum yang dipergunakan adalah bahan hukum primer terdiri dari UndangUndang Dasar 1945, Qanun Nomor 12 Tahun 2003 Tentang Minuman Khamar dan sejenisnya, Qanun Nomor 13 Tahun 2003 Tentang Maisier (perjudian) dan Qanun Nomor 14 Tahun 2003 Tentang Khalwat (perbuatan Mesum) dan Peraturan Gubernur Provinsi Nanggroe Aceh Darussalam Nomor 10 Tahun 2005 tentang Petunjuk Teknis Pelaksanaan Uqubat Cambuk. Bahan Hukum sekunder terdiri dari buku-buku, jurnaljurnal hukum, pendapat para sarjana yang berhubungan dengan permasalahan dalam penelitian ini. Analisa bahan hukum dilakukan dengan menggunakan metode kualitatif.

\section{Pembahasan \\ Hukuman Cambuk}

Hukuman cambuk merupakan salah satu jenis hukuman yang telah ditentukan dalam AlQur'an Surat An-Nuur ayat 2 untuk tindak pidana zina, dan Surat An-Nuur ayat 4 untuk tindak pidana menuduh orang lain berzina (Qadzaf).

8 M. Din, 2009, Stimulasi Pembangunan Hukum Pidana Nasional Dari Aceh Untuk Indonesia, Bandung: UNPAD Press, hlm. 144. 
Ayat tersebut menjelaskan jumlah cambukan untuk pezina 100 kali, sedangkan untuk perbuatan menuduh orang lain berzina (Qadzaf) 80 kali. Sanksi meminum-minuman keras dalam beberapa hadis disebutkan 40 kali cambukan.

Pelaksanaan hukuman cambuk di Aceh berbeda dengan beberapa negara yang melaksanakan hukuman cambuk seperti di Malaysia, Pakistan dan Singapura. Di Malaysia pelaksanaan Hukuman cambuk dilaksanakan di dalam gedung tertutup (di dalam penjara), yang tidak disaksikan oleh masyarakat. Pelaksanaan hukuman cambuk dilakukan dengan cara mengikat ketua tangan terpidana di tiang balok yang sudah disediakan dengan posisi terpidana setengah telungkup. Begitu juga di Singapura, pelaksana-an hukuman cambuk dilaksanakan dengan posisi terpidana setengah telungkup dan tangan terikat. Di Pakistan, hukuman cambuk dilaksanakan di lapangan terbuka dan disaksikan oleh masyarakat umum serta terpidana menjalani hukuman cambuk dengan tangan terikat.

Bentuk ancaman hukuman cambuk dimaksudkan sebagai upaya memberi kesadaran pada pelaku dan segaligus menjadi peringatan bagi masyarakat agar tidak melakukan perbuatan yang dilarang dalam Qanun Aceh, di samping itu hukuman cambuk sebagai upaya pendidikan dan pembinaan, sehingga sipelaku akan menyadari dan menyesali kesalahan yang dilakukan dan mengantarkannya untuk memposisikan diri dalam taubatan nasuha. Pelaksanan hukuman cambuk di depan umum dimaksudkan sebagai upaya preventif dan lebih efektif karena terpidana merasa malu dan tidak menimbulkan resiko pada keluarganya. Jenis hukuman cambuk juga menjadikan biaya yang harus ditanggung oleh pemerintah lebih murah diban-dingkan dengan jenis hukuman lainnya seperti yang dikenal dalam sistem KUHP yang berlaku sekarang ini.

Pelaksanaan hukuman cambuk terhadap pelaku perbuatan pidana Qanun Aceh diatur dengan Peraturan Gubernur Provinsi Nanggroe Aceh Darussalam Nomor 10 Tahun 2005 Tentang Petunjuk Teknis Pelaksanaan Uqubat Cambuk. UU Nomor 11 Tahun 2006 menentukan bahwa pengaturan pelaksanaan syari'at Islam harus diatur melalui Qanun Aceh, oleh karena itu pelaksanaan hukuman cambuk yang selama ini dilakukan di Aceh berdasarkan Peraturan Gubernur hanyalah bersifat sementara/belum final dan akan terus disempurnakan, yang nantinya akan diatur melalui Qanun.

Hukuman cambuk di Aceh dilaksanakan setelah adanya keputusan Mahkamah Syar'iyah yang mempunyai kekuatan hukum tetap. Terpidana tidak ditahan untuk menunggu eksekusi hukuman cambuk. Pada waktu eksekusi dilaksanakan jaksa penuntut umum akan mengirim surat panggilan untuk hadir pada waktu dan tempat yang telah ditentutan. Kehadiran terpidana cambuk untuk menjalani eksekusi bersifat sukarela atas kesadarannya sendiri. Jaksa penuntut umum tidak pernah berusaha untuk melakukan penjemputan paksa.

Tempat dan waktu pencambukan ditentukan oleh Jaksa dan berkoodinasi dengan Ketua Mahkamah Syar'iyah untuk menyiapkan hakim pengawas yang harus hadir pada waktu pelaksanaan hukuman cambuk, Kepala Dinas Kesehatan untuk menyiapkan dokter yang akan memeriksa kesehatan terhukum sebelum dan sesudah pelaksanaan pecambukan dan mengirimkan nama dokter yang ditunjuk pada Jaksa sebelum waktu pemeriksaan dan Instansi yang membawahi Wilayatul Hisbah untuk menyiapkan pecambuk dan memberitahukan pada Jaksa tentang kesiapan pecambuk sebelum waktu pencambukan. Wilayatul Hisbah adalah lembaga yang bertugas mengawasi, membina, dan melakukan advokasi terhadap pelaksanaan Peraturan Perundang-Undangan bidang Syari'at Islam dalam rangka melaksanakan amar ma'ruf nahi mungkar.

Jaksa menghadirkan terhukum di tempat pelaksanaan hukuman cambuk dengan terlebih dahulu memberitahukan secara tertulis selambat-lambatnya satu hari sebelum tanggal pencambukan kepada keluarga dan Geuchik Gampong tempat tinggalnya. Geuchik adalah orang yang dipilih dan dipercaya oleh masyarakat serta diangkat oleh pemerintah kabupaten/Kota untuk memimpin pemerintahan Gampong. Gam- 
pong adalah suatu wilayah yang ditempati oleh sejumlah penduduk sebagai kesatuan masyarakat yanag terendah dan berhak menyelenggarakan rumah tangganya sendiri. Sebelum dilaksanakan hukuman cambuk si terhukum diperiksa kesehatannya oleh dokter yang ditunjuk oleh Kepala Dinas, dan apabila menurut hasil pemeriksaan tidak dapat menjalani hukuman cambuk, maka pelaksanaan pecambukan akan ditunda sampai yang bersangkutan dinyatakan sehat untuk menjalani hukuman cambuk dan dikembalikan kepada keluargannya, terhukum atau keluargnya melaporkan keadaan kesehatan terhukum kepada jaksa secara berkala. Apabila dalam waktu satu bulan terhukum atau keluarganya tidak menyampaikan laporan tanpa alasan yang sah maka Jaksa harus memanggil terhukum untuk mengetahu keadaan kesehatannya.

Pelaksanaan hukuman cambuk terhadap terhukum perempuan yang hamil atau menyusui anak dilakukan setelah selesai menyapih anaknya dan sebelum melaksanakan hukuman dikembalikan pada keluargannya, setelah menyapih anaknya terhukum wajib melapor kepada Jaksa Penuntut Umum untuk dilaksanakan hukuman cambuk. Sebelum dilaksanakan hukuman cambuk dapat diberikan bimbingan rohani singkat oleh seorang ulama atas permintaan Jaksa atau terhukum. Jaksa hanya boleh membacakan indentitas terhukum, perbuatan pidana yang dilakukan dan hukuman yang dijatuhkan Mahkamah.

Hukuman cambuk dilaksanakan di suatu tempat terbuka yang dapat dihadiri oleh orang banyak dengan tidak dibenarkan untuk memoto atau merekam, kecuali untuk kepentingan dokumentasi Kejaksaan dan Polisi Wilayatul Hisbah. Cambuk sebagai alat pemukul yang terbuat dari rotan yang berdiameter 0,75 sampai dengan 1 (satu) senti meter dengan panjang 1 (satu) meter dan tidak mempunyai ujung ganda dan pada pangkalnya ada tempat pegangannya. Pelaksanaan hukuman cambuk dilakukan di atas alas (panggung) berukuran minimal $3 \times 3$ meter. Jarak antara terhukum dengan pecambuk antara 0,70 meter sampai 1 (satu) meter dengan posisi pecambuk berdiri di sebelah kiri terhu- kum. Jarak antara pecambuk dengan orang yang menyaksikan paling dekat 12 (dua belas) meter. Jaksa, hakim pengawas, dokter yang ditunjuk dan petugas pencambuk berdiri di atas atau disekitar alas (panggung) berukuran $3 \times 3$ meter, selama pencambukan berlangsung. ${ }^{9}$

Hukuman cambuk dilaksanakan di tempat terbuka yang dapat dikunjungi masyarakat luas karena Al Qur'an meminta untuk dilaksanakan seperti itu. Hukuman cambuk disamping merupakan hukuman duniawi, juga merupakan bagian dari ajaran agama. Dengan demikian hukuman cambuk merupakan bagian dari pernyataan taubat yang diharapkan dapat mengampuni dosa di akhirat kelak.

Pecambuk hadir di tempat pencambukan dengan memakai penutup wajah yang terbuat dari kain yang telah disediakan Jaksa. Cambukan dilakukan pada bahagian tubuh kecuali kepala, muka, leher, dada dan kemaluan (bahu sampai pinggul). Pecambuk dapat membuat kudakuda dengan jarak antara kaki kiri dan kanan maksimal $50 \mathrm{~cm}$ dan dapat menekuk tangan serta mengayunkan cambuk kesamping atau ke belakang, asalkan posisi ujung tangannya tidak lebih tinggi dari bahu, pecambuk dapat meminta tukar cambuk yang dia gunakan apabila dirasakan tidak nyaman. Apabila pecambuk tidak sanggup menyelesaikan pekerjaannya maka pecambuk akan dilanjutkan oleh pecambuk lainnya.

Pencambukan dilakukan atas perintah atau aba-aba dari Jaksa dan cambukan yang sudah dilaksanakan tidak dapat diulang kembali walaupun ada yang menganggapnya tidak memenuhi syarat. Jaksa akan menegur, memperbaiki posisi atau menukar pecambuk apabila cambukan dilakukan tidak pada bahagian punggung (bahu sampai pinggul), membuat kudakuda dengan jarak antara kaki kiri dan kanan lebih dari $50 \mathrm{~cm}$, mengayunkan cambuk lebih tinggi dari bahu dan apabila pecambuk tidak sanggup menyelasaikan pekerjaannya maka pe-

Lihat Pasal 6 Peraturan Gubernur Provinsi Nanggroe Aceh Darussalam Nomor 10 Tahun 2005 Tentang Petunjuk Teknis Pelaksana Uqubat Cambuk. 
cambuk akan dilanjutkan oleh pecambuk lainnya. ${ }^{10}$

Terhukum pada saat pencambukan diharuskan menggunakan baju yang telah disediakan jaksa dan berada pada posisi bebas dan berdiri tanpa penyangga dan atas permintaan terhukum atau dokter, terhukum dapat dicambuk sambil duduk bersimpuh atau berdiri dengan penyangga, namun harus dalam keadaan bebas. Dalam Peraturan Gubernur ditentukan bahwa pada saat pencambukan terhukum berada didalam posisi berdiri tanpa penyangga bagi terhukum laki-laki dan posisi duduk bagi terhukum perempuan. Rancangan Qanun memberikan kebebasan pada terhukum atau dokter untuk memilih apakah pencambukan dilakukan sambil duduk bersimpuh atau berdiri.

Pelaksanaan hukuman cambuk dapat dihentikan sementara, apabila: pertama, terhukum terluka akibat pencambukan dan atas pertimbangan medis, dokter memerintahkan untuk menghentikan sementara pencambukan dan mengembalikan terhukum ke tempat penahanan; dan kedua, terhukum tidak dihalangi dan tidak dikejar petugas untuk melarikan diri dari tempat pecambukan sebelum hukuman cambuk selesai dilaksanakan. Pencambukan akan dilakukan kembali setelah si terhukum menyerahkan diri kepada jaksa atau di datangkan oleh polisi. ${ }^{11}$

Pelaksanaan Pencambukan melibatkan hakim pengawas. Hakim pengawas memiliki tugas antara lain: pertama, mengingatkan Jaksa agar menunda pelaksanaan hukuman cambuk apabila hukuman cambuk tidak dilaksanakan di tempat terbuka, pelaksanaan hukuman cambuk tidak di laksanakan diatas alas (panggung) berukuran minimal $3 \times 3$ meter, tempat berdiri tercambuk dengan masyarakat yang menyaksikan kurang dari 12 (dua belas) meter, Jaksa, hakim pengawas, dokter yang telah ditunjuk dan petugas pencambuk tidak berdiri di atas atau disekitar alas (panggung) berukuran $3 \times 3$ meter dan Jak-

10 Lihat Pasal 7 Peraturan Gubernur Provinsi Nanggroe Aceh Darussalam Nomor 10 Tahun 2005 Tentang Petunjuk Teknis Pelaksana Uqubat Cambuk.

11 Lihat Pasal 11 Peraturan Gubernur Provinsi Nanggroe Aceh Darussalam Nomor 10 Tahun 2005 Tentang Petunjuk Teknis Pelaksana Uqubat Cambuk. sa membolehkan atau membiarkan pengambilan gambar atau merekam pelaksanaan pencambukan yang bukan untuk kepentingan dokomentasi kejaksaan atau Wilayatul Hisbah; kedua, Hakim Pengawas mengingatkan Jaksa agar tidak memerintahkan pecambuk melakukan pencambukan atas terhukum perempuan yang sedang hamil atau menyusui, terhukum yang pencambukannya diberhentikan sementara oleh dokter atas pertimbangan medis atau terhadap terhukum yang melarikan diri dari tempat pencambukan sebelum pelaksanaan pencambukan selesai; ketiga, memerintahkan Jaksa untuk menukar pecambuk apabila setelah diingatkan tetap melakukan pencambukan dengan posisi tangan melebihi tinggi bahu atau membuat kudakuda dengan jarak antara kaki kiri dan kanan melebihi $50 \mathrm{~cm}$; keempat, mengingatkan atau menegur Jaksa apabila terhukum tidak menggunakan baju yang telah disediakan Jaksa pada saat pencambukan, tercambuk tidak berada dalam posisi bebas atau pencambukan dilakukan tidak sesuai dengan permintaan terhukum atau dokter untuk dicambuk dalam keadaan duduk bersimpuh atau berdiri dengan penyangga dalam keadaam bebas.

Seusai pencambukan, Jaksa membuat berita acara pelaksanaan pencambukan dan menandatanganinya bersama-sama dengan hakim pengawas dan dokter sebagai saksi. Jaksa membawa terhukum ketempat yang telah disediakan untuk dibebaskan dan Jaksa menyerahkan satu lembar salinan berita acara kepada terhukum atau keluargannya sebagai bukti telah menjalankan seluruh atau sebagian hukuman. Apabila si terhukum meninggal dunia pada saat pelaksanaan pencambukan maka Jaksa membuat berita acara penyerahan jenazah kepada keluargannya berserta jenazah untuk dikebumikan, dan apabila Jaksa menguburkan jenazah, Jaksa akan membuat berita acara penguburan jenazah untuk diserahkan pada keluargannya.

Prosudur pelaksanaan hukuman cambuk sebagaimana disebutkan di atas, terlihat dengan jelas bahwa standar pelaksanaan dilakukan dengan cermat dengan mempertimbangkan keadilan hukum dan hak asasi manusia. Penye- 
rahan kewenangan eksekusi kepada petuga Wilayatul Hisbah dibawah kordinasi kejaksaan menunjukkan penghormatan pada legalitas kewenangan eksekusi serta kecakapan dalam melaksanakan pencambukan. Pelaksanaan di depan publik menunjukkan adanya motif filosofis untuk mempermalukan pelaku atas perbuatan pelanggaran hukum yang dilakukannya, dan dengan kesediannya menjalani eksekusi hukuman memungkinkannya memperoleh jalan terhormat baginya untuk berintergrasi kembali ke dalam masyarakat tanpa kekhawatiran adanya stigma kriminal. Pembatasan sasaran pencambukan pada badan terpidana menunjukkan penghormatan pada kehidupan masa depan terpidana. Pukulan cambuk diharapkan hanya member rasa sakit fisik yang bersifat sementara dan tidak menimbulkan cedera permanen, terutama pada bagian tubuh yang bersifat terbuka. ${ }^{12}$

\section{Relevansi Hukuman Cambuk dalam Pembaha- ruan Hukum Pidana}

Relevansi hukuman cambuk sebagai salah satu bentuk pemidanaan dalam pembaharuan hukum pidana. ${ }^{13}$ Kata relevansi dalam tulisan ini untuk mencari sangkut paut dan berguna langsung hukuman cambuk dalam pembaharuan hukum pidana. Hukuman cambuk bersangkut paut dan berguna langsung dalam pembaharuan hukum pidana apabila sesuai atau tidak bertentangan dengan cita hukum masyarakat Indonesia pada umumnya.

Berdasarkan catatan rihlah Ibnu Battutah, Islam masuk ke Aceh pada penghujung abad pertama Hijriah, yang dibawa pedagang arab dan India yang melakukan perdagangan di sepanjang pesisir Aceh. Penyebaran melalui metode penetrasi damai, toleransi membangun dan membaur dengan tradisi yang ada. ${ }^{14}$ Masuknya

12 Natangsa Surbakti, "Pidana Cambuk Dalam perpektif Keadilan Hukum dan Hak Asasi Manusia di Provinsi Naggroe Aceh Darussalam", Jurnal Hukum No. 3 Vol. 17 Juli 2010, Yokyakarta: Fakultas Hukum Universitas Islam Indonesia, hlm. 468.

13 Relevan artinya kait mengait, bersangkut paut atau berguna langsung. Lihat Departeman Pendidikan dan Kebudayaan, Kamus Besar Bahasa Indonesia, Jakarta: Balai Pustaka, hlm. 830.

14 Hasanudin Yusuf A, "Sejarah dan Perkembangan Islam di Aceh", Jurnal Ar-Raniry, Edisi No. 82 Tahun 3003, Banda Aceh: Institut Agama Islam Negeri Ar-Raniry, hlm. 5.
Islam membawa perubahan dalam masyarakat Aceh. Nilai-nilai Islam mulai diaplikasikan dan diterapkan dalam kehidupan masyarakat yang sebelumnya beragama Hindu. Penerapan syari'at Islam mulai ada dan berkembang pada kerajaan Aceh, hingga puncaknya pada kesultanan Iskandar Muda. ${ }^{15}$

Berdasarkan manuskrip-manuskrip karya ulama Aceh seperti karya Syekh Nuruddin arRaniry, karya Abdurrauf as Singkili dan karyakarya lainnya, hukum Islam pada masa Iskandar Muda diterapkan secara kaffah dengan mazhab Syafi'i yang meliputi bidang; ahwal al-syakhskiyyah (hukum Keluarga), mu'amalat maaliyah (perdata, jinayah (hukum pidana), uqubah (hukuman), murafa'ah, iqtshadiyah (peradilan), dusturryah (perundang-undangan), akhlaqiyyah (moral) dan 'alaqah dauliyah (kenegaraan) ${ }^{16}$.

Pelaksanaan hukum Islam telah dipraktikan di berbagai kesultanan yang ada di Nusantara. Rif'yal Ka'bah menulis bahwa sebelum kedatangan penjajah Belanda, hukum Islam telah merupakan hukum positif di kerajaan-kerajaan Islam menggantikan kerajaan Hindu/Budha berarti untuk pertama kalinya hukum Islam telah ada di Indonesia sebagai hukum positif. Para penguasa ketika itu memposisikan hukum Islam sebagai hukum negara. ${ }^{17}$

Masyarakat Aceh sejak dahulu semasa kesultanan Aceh telah melaksanakan Syaria'at Islam untuk mengatur kehidupan dalam bermasyarakat. Penghayatan terhadap ajaran agama Islam dalam jangka panjang itu melahirkan budaya Aceh yang tercermin dalam kehidupan adat. Adat itu lahir dari renungan para ulama, kemudian dipraktekkan, dikembangkan dan dilestarikan, lalu disimpulkan menjadi "adat bak Poteumeureuhom. Hukum bak Syah Kuala, Qanun bak Putro Phang. Reusam bak Laksamana". Artinya hukum adat ditangan pemerintah dan

15 M. Syadli Z A, "Pendidikan Islam di Kesultanan Aceh: Ulama, Meunasah dan Rangkang", Jurnal al Qalam, Vol. 20 No. 96 Tahun 2003, Banten: Sekolah Tinggi Agama Islam Sultan Maulana Hasanudin, hlm. 133-139.

16 Syamsul Bahri, "Pelaksanaan Syariat Islam di Aceh sebagai Bagian Wilayah Negara Kesatuan Republik Indonesia (NKRI)", Jurnal Dinamika Hukum, Vol 12 No. 2 Mei 2012, Purwokerto: Fakultas Hukum Universitas Jendral Sudirman, hlm. 360.

17 Rifyal Ka'bah, 1999, Hukum Islam di Indonesia, Jakarta: Universitas Yasri, hlm. 264. 
hukum syari'at ada di tangan ulama. Kata-kata ini merupakan pencerminan dari perwujudan syari'at Islam dalam praktik hidup sehari-hari bagi masyarakat Aceh.

Pembaharuan hukum pidana pada hakekatnya merupakan suatu upaya melakukan peninjauan dan pembentukan kembali (reorientasi dan reformasi) hukum pidana yang sesuai dengan nilai-nilai sentra sosio-politik, sosio-filosofi dan nilai-nilai sosio-kultural masyarakat Indonesia. ${ }^{18}$ Penggalian nilai-nilai yang terdapat dalam masyarakat Indonesia merupakan syarat mutlak harus dilakukan sebagai usaha pembaharuan hukum pidana Indonesia agar hukum pidana Indonesia di masa depan sesuai dengan sosio-politik, sosio-filosofik dan nilai-nilai sosiokultural masyarakat Indonesia. Pada pelaksanaannya penggalian nilai ini bersumber pada hukum adat, hukum pidana positif (KUHP), hukum agama, hukum pidana negara lain, serta kesepakatan-kesepakatan internasional mengenai materi hukum pidana. ${ }^{19}$

Undang-Undang Dasar 1945 merupakan sumber hukum yang paling mendasar, hukum tertinggi yang mengandung nilai, asas dan norma yang harus dipatuhi, dijunjung tinggi dan dilaksanakan dalam setiap pengambilan keputusan dan/atau kebijakan hukum baik oleh pemerintah, legeslatif dan badan yudisial, serta rakyat pada umumnya, oleh karena itu dalam sistem hukum nasional yang hendak dibangun dan pelaksanaannya dalam bentuk politik hukum nasional. ${ }^{20}$ Nilai-nilai fundamental yang terkandung dalam dasar falsafah Negara Pancasila yang termuat dalam pembukaan UUD 1945 dan seluruh pasal-pasalnya.

18 Barda Nawawi Arief, 2008, Kebijakan Hukum Pidana, Jakarta:Kencana Prenada Media Group, hlm. 25.

19 Marcus Priyo Gunarto, “Asas Keseimbangan dalam Konsep Rancangan Undang-Undang Kitab Undang-Undang Hukum Pidana", Mimbar Hukum, Volume 24 No. 1 Februari 2012, Yokyakarta: Fakultas Hukum Universitas Gajah Mada, hlm. 86.

20 Endang Sutrisno, "Mengukuhkan Paradigma Hukum di Era orde Reformasi", Jurnal Ilmiah, Edisi 01/Juni/2005, Cirebon: Fakultas Hukum Universitas Swadaya Gunung Jati, hlm. 34. sebagi landasan falsafah dan konstitusional negara. ${ }^{21}$

Sila pertama Pancasila, Ketuhanan yang Maha Esa, memberikan isnspirasi bahwa hukum nasional harus bernapaskan moral religious yang beradab, bukan bedasarkan hukum agama dari suatu agama tertentu; Sila Kemanusian yang Adil dan Beradab, memberikan inspirasi bahwa hukum nasional harus mengindahkan hak-hak asasi manusia; Sila Persatuan Indonesia akan memberikan inspirasi bahwa sistem hukum nasional harus mencerminkan jiwa dan rasa keadilan bagi seluruh rakyat Indonesia; Sila Kerakyatan yang dipimpin oleh hikmah kebijaksanaan dalam permusyawaratan/perwakilan harus dirumuskan dengan mengikutsertakan atau memperhatikan aspirasi dan rasa keadilan seluruh rakyat Indonesia. Sila Keadilan Sosial bagi Seluruh Rakyat Indonesia akan member aspirasi tidak mengenal konsep keadilan yang sematamata berlingkup individu, melaikan juga keadilan yang menuju terselenggaranya kesejahteraan bersama ${ }^{22}$. Karateristik tersebut merupakan pencerminan dari asas-asas hukum yang terkandung dalam Pancasila meliputi asas religius, asas kemanusiaan dan asas kemasyaraka$\tan .^{23}$

Bangsa Indonesia terdiri atas berbagai suku bangsa dengan budaya dan agama yang berbeda, ditambah dengan keanekaragaman yang ditinggalkan oleh pemerintah kolonial dahulu, bukanlah mudah untuk mewujudkan satu hukum pidana nasional yang mampu mengayomi dan memayungi seluruh bangsa dan Negara. Pembaharuan hukum wajib menggunakan wawasan nasional yang merupakan tritunggal yang tidak dapat dipisahkan satu dari yang lain, yaitu: wawasan kebangsaan, wawasan nusantara dan wawasan bhineka tunggal ika. Dengan mempergu-

21 T. Gayus Lumbun, "Budaya Hukum Mempengaruhi Pelestarian Lingkungan", Jurnal Ilmu Hukum "Era Hukum”, No. 1 Tahun 11 September 2003, Jakarta: Fakultas Hukum Universitas Tarumanegara, hlm. 23.

22 M. Ali Mansyur, "Pancasila Sebagai Dasar Pengembangan Ilmu Hukum Indonesia", Jurnal Hukum, Vol. XV No. 1 Juni 2005, Semarang: Fakultas Hukum Unversitas Sultan Agung, hlm. 13.

23 Maleha Soemarno, "Negara Hukum Indonesia Ditinjau dari Sudut Teori Tujuan Negara", Jurnal Hukum \& Pembangunan, Tahun 37 No. 2 April-Juni 2007, Jakarta: Fakultas Hukum Universitas Indonesia, hlm. 318. 
nakan ketiga wawasan itu secara serentak dan terpadu berbagai asas dan kaedah hukum Islam, juga hukum adat dan hukum eks barat akan menjadi integral hukum nasional, baik hukum nasional yang tertulis maupun hukum nasional yang tidak tertulis atau hukum kebiasaan ${ }^{24}$.

RKUHP yang disampaikan pemerintah pada tanggal 11 Desember 2012 kepada DPR, Pasal 1 ayat (1) menyatakan bahwa "Tiada seorang pun dapat dipidana atau dikenakan tindakan, kecuali perbuatan yang dilakukan telah ditetapkan sebagai tindak pidana dalam peraturan perundang-undangan yang berlaku pada saat perbuatan itu dilakukan". Dengan demikian asas legalitas formal yang terdapat dalam pasal ini memberikan amanat bahwa sumber hukum yang utama untuk menentukan apakah suatu perbuatan termasuk sebagai tindak pidana atau bukan adalah UU atau Peraturan Daerah.

Pasal 2 ayat 1 RKUHP menentukan bahwa: Ketentuan sebagaimana dimaksud dalam Pasal 1 ayat (1) tidak mengurangi berlakunya hukum yang hidup dalam masyarakat yang menentukan bahwa seseorang patut dipidana walaupun perbuatan tersebut tidak diatur dalam peraturan perundangundangan.

Isi Pasal ini bukanlah hal yang baru, tetapi hanya melanjutkan ide yang yang sudah ada sebelumnya. Pengakuan hukum tidak tertulis/hukum adat tersebut sebelumnya diatur pada Pasal 5 ayat (3) sub b UU Nomor 1 Drt 1951 yang menentukan:

“... Bahwa suatu perbuatan yang menurut hukum yang hidup harus dianggap perbuatan pidana, akan tetapi tiada bandingannya dalam Kitab Hukum Pidana Sipil, maka dianggab diancam dengan hukum yang tidak lebih dari tiga bulan penjara dan/atau denda lima ratus rupiah, yaitu sebagai hukum pengganti bila mana hukuman adat yang dijatuhkan tidak diakui oleh pihak yang terhukum, bila mana hukum adat yang dijatuhkan itu menurut pikiran hakim melapaui hukuman kurungan atau denda yang dimaksud di atas, maka terdakwa dapat dikenai hukuman peng-

24 Mardani, "Kedudukan Hukum Islam Dalam Sistem Hukum Nasional", Jurnal Hukum, No. 2 Vol. 16 April 2009, Yogyakarta: Fakultas Hukum Universitas Islam Indonesia, hlm. 271-272. ganti setinggi 10 tahun penjara, dengan pengertian bahwa hukum adat yang tidak selaras lagi dengan zaman senantiasa diganti seperti tersebut di atas. ${ }^{25}$

Selain Pasal 5 ayat (3) sub b UU Drt 1951 tersebut, dalam UU Nomor 48 Tahun 2009 Tentang Kekuasaan Kehakiman, terdapat beberapa ketentuan yang memungkinkan hakim mendasarkan pada hukum yang tidak tertulis, misalnya Pasal 5 yang menentukan bahwa:

Hakim dan hakim konstitusi wajib menggali, mengikuti dan memahami nilai-nilai hukum dan rasa keadilan yang hidup dalam masyarakat.

Kemudian Pasal 10 ayat (1) yang menentukan bahwa:

Pengadilan dilarang menolak untuk memeriksa, mengadili dan memutus suatu perkara yang diajukan dengan dalih bahwa hukum tidak ada atau kurang jelas, melaikan wajib untuk memeriksa dan mengadili.

Pasal 50 juga menentukan bahwa:

Putusan pengadilan selain harus memuat alasan dan dasar putusan, juga memuat pasal tertentu dari peraturan perundangundangan yang bersangkutan atau sumber tak tertulis yang dijadikan dasar untuk mengadili.

Hakim dalam memeriksa dan memutus berdasarkan hukum tidak tertulis, hakim dapat menetapkan sanksi berupa pemenuhan kewajiban adat setempat atau kewajiban menurut hukum yang hidup dalam masyarakat yang harus dilaksanakan oleh pelaku tindak pidana, diharapkan dapat mengembalikan keseimbangan dalam masyarakat yang terganggu karena dilakukannya suatu tindak pidana. Sanksi pemenuhan kewajiban adat setempat atau kewajiban menurut hukum yang hidup dalam masyarakat merupakan jaminan bahwa nilai dan norma yang hidup dalam masyarakat setempat masih tetap dilindungi untuk memenuhi rasa keadilan.

Asas legalitas yang terkadung dalam Pasal 1 ayat (1) RKUHP memberi makna bahwa suatu perbuatan yang tidak tercantum dalam perun-

25 Lihat Pasal 5 ayat (3) sub b Undang-Undang Nomor 1 Drt 1975. 
dang-undangan sebagai suatu perbuatan pidana tidak dapat dipidana, perbuatan pidana harus dirumuskan sebelumnya dalam perundang-undangan. Tidak dapat dipidana hanya berdasarkan kebiasaan yang hidup dalam masyarakat, artinya pelanggaran terhadap kaedah-kaedah kebiasaan dengan sendirinya belum tentu menghasilkan perbuatan pidana.

Perumusan asas legalitas formal yang terdapat dalam Pasal 1 ayat (1) diperluas dengan asas legalitas matriel yang terdapat dalam Pasal 2 ayat (1) yang secara emplisit mengakui hukum tidak tertulis yang hidup dalam masyarakat hukum Indonesia atau tindak pidana adat, sepanjang berorientasi pada nilai-nilai yang terkandung dalam Pancasila, hak asasi manusia, prinsip-prinsip hukum umum yang diakui oleh masyarakat bangsa-bangsa. Asas legalitas tidak hanya diartikan sebagai kepastian hukum fomil, tetapi juga kepastian hukum materiel atau tidak hanya diartikan sebagai nullum delictum sine legi, tetapi juga nullum delictum sine ius. Dengan demikian RKUHP tidak lagi menganut asas legalitas yang bersifat absolut dan telah mengakui ajaran sifat melawan hukum materiel dalam fungsi yang positif, meskipun suatu perbuatan tidak memenuhi rumusan perbuatan pidana dalam UU tertulis, hakim dapat menjatuhkan pidana apabila perbuatan tersebut dianggap tercela, bertentangan dengan keadilan dan norma sosial yang hidup dalam masyarakat.

Secara garis besar penduduk Indonesia dapat dibagi dalam dua kelompok, di bagian barat Indonesia penduduknya kebanyakan adalah suku melayu sementara di timur adalah suku Papua yang mempunyai akar dikepulauan Melanesia. Banyak penduduk Indonesia menyatakan dirinya sebagai bagian dari kelompok suku spesifik, yang dibagi menurut bahasa dan asal daerah, misalnya Jawa, Sunda atau Batak, Karo, Minangkabau, Melayu di Sumatera dan sebagainya. Islam adalah agama mayoritas yang dipeluk oleh sekitar 85,2 \% penduduk Indonesia, yang menjadikan Indonesia Negara dengan penduduk muslim terbanyak di dunia. Indonesia terdiri dari berbagai suku bangsa, agama serta kepercayaan yang berbeda. Dengan keanekaragaman suku yang terdapat di Indonesia menimbulkan konsekwensi adanya perbedaan adat dan kebiasaan dari masing-masing suku. Mengingat wawasan Bhineka Tunggal Ika nampaknya bidangbidang hukum seperti hukum pidana dan hukum perdata sulit untuk diunifikasi, apalagi hukum keluarga dan waris. Penerapan prinsip unifikasi hanya dapat dilakukan pada bidang-bidang hukum yang “"netral” sifatnya, yang terutama menyangkut kegiatan perdagangan, selebihnya harus lebih diserahkan pada yurispudensi dan bahkan Peraturan Daerah ${ }^{26}$.

Perumusan tindak pidana yang diamanatkan oleh Pasal 1 ayat (1) RKUHP harus ditetapkan dalam peraturan perundang-undangan berupa UU dan Peraturan Daerah. Untuk menghormati keanega ragaman budaya dan agama yang ada di Indonesia dalam kerangka Bhineka Tunggal Ika, perumusan tindak pidana secara legalitas formal sebaiknya dilakukan melalui Peraturan Daerah. Tidak ada negara yang begitu heterogen seperti Indonesia yang akan mampu melaksanakan unifikasi hukum secara menyeluruh. Bahkan tidak juga Jerman yang begitu homogin kulturnya mampu melaksanakannya, mungkin hanya negara yang sangat homogin seperti Jepang dan Korea yang cocok untuk melaksanakan hukum yang bersifat unifikasi. ${ }^{27}$

\section{Penutup \\ Simpulan}

Pelaksanaan hukuman cambuk di provinsi Aceh didasarkan pada Al-Quran dan Sunnah yang dikonkritkan melalui Qanun dengan memperhatikan kebutuhan lokal masyarakat Aceh dengan memperhatikan isu-isu hak asasi manusia dan konvensi menentang penyiksaan dan perlakuan atau penghukuman lain yang kejam, tidak manusiawi atau merendahkan martabat manusia.

26 Budiono Kusumohamidjoyo, "Politik Hukum dan pembangunan Hukum Nasional Dalam PJPT II”, Pro Justitia Majalah Hukum, 1993, Bandung: Fakultas Hukum Universitas Pajajaran, hlm. 77-78.

27 Maroni, "Problematik Penggantian Hukum-Hukum Kolonial dengan Hukum-hukum Nasional sebagai Politik Hukum", Jurnal Dinamika Hukum, Vol. 12 No 1 Januari 2012, Purwokerto: Fakultas Hukum Jenderal Sudirman, hlm. 89. 
Pasal 2 RKUHP mengakui hukum yang hidup dalam kehidupan masyarakat Indonesia atau ketentuan yang tidak tertulis yang hidup dalam masyarakat yang berlaku di daerah masing-masing. Penduduk Indonesia mayoritas beragama Islam, melaksanakan perintah agama merupakan suatu kewajiban bagi umatnya. Hukum pidana Islam menentukan salah satu jenis pidana adalah pidana cambuk terhadap perbuatan-perbuatan tertentu, menetapkan hukuman cambuk sebagai salah satu jenis pidana dalam konsep RKUHP merupakan suatu keharusan karena negara mempunyai kewajiban untuk menjalankan syari'at agama bagi pemeluknya.

\section{Saran}

Ada dua saran yang dapat diberikan. Pertama, pelaksanaan hukuman cambuk di provinsi Aceh bagi pelaku qanun Aceh yang telah diputus Mahkamah Syar'iyah dan telah mempunyai kekuatan hukum tetap hendaknya dilakukan penahanan sebelum pelaksanaan hukuman cambuk, agar supaya terpidana tidak melarikan diri atau tidak bersedia melaksanakan hukuman cambuk.

Kedua, hukum yang hidup atau hukum yang tidak tertulis yang ada di Indonesia beraneka ragam di samping agama yang dianut oleh penduduknya, untuk menghormati kebhinekaan sebaiknya pengaturan perbuatan pidana atau substansi hukum pidana diserahkan pada perkembangan yurispudensi dan Peraturan Daerah.

\section{Daftar Pustaka}

Ablisar, Madiasa. "Pemberlakuan Hukum Pidana Qanun Aceh". Equality Jurnal Hukum. Vol 16 No. 2 Agustus 2011. Medan: Fakultas Hukum Universitas Sumatera Utara;

Abubakar, Al-Yasa' dan M. Daud Yoesoef. "Qanun sebagai Pelaksana Otonomi Khusus di Provinsi Nanggroe Aceh Darussalam". Jurnal Legislasi Indonesia. Vol. 1 No. 3 November 2004. Jakarta: Direktorat Jenderal Perundang-undangan Departemen Hukum dan HAM RI.;

Anggriani, Jum. "Kedudukan Qanun Dalam Sistem Pemerintah Daerah dan Mekanisme Pengawasannya". Jurnal Hukum. No. 3
Vol. 18 Juli 2011. Yokyakarta: Fakultas Hukum Universitas Islam Indonesia;

Arief, Barda Nawawi. 2008. Kebijakan Hukum Pidana. Jakarta: Kencana Prenada Media Group;

Bahri, Syamsul. "Pelaksanaan Syariat Islam di Aceh sebagai Bagian Wilayah Negara Kesatuan Republik Indonesia (NKRI)". Jurnal Dinamika Hukum. Vol 12 No. 2 Mei 2012. Purwokerto: Fakultas Hukum Universitas Jenderal Sudirman;

Din, M. 2009. Stimulasi Pembangunan Hukum Pidana Nasional Dari Aceh Untuk Indonesia. Bandung: UNPAD Press;

Gunarto, Marcus Priyo. "Asas Keseimbangan dalam Konsep Rancangan Undang-Undang Kitab Undang-Undang Hukum Pidana". Jurnal Mimbar Hukum, Volume 24 No. 1 Februari 2012. Fakultas Hukum Universitas Gajah Mada. Yokyakarta;

Hadjar, Ibnu. "Syariat Islam dan Hukum Positif di Indonesia". Al-Muwarid (Jurnal Hukum Islam). Edisi XVI Tahun 2006. Yokyakarta: Program Studi Hukum Islam Fakultas IImu Agama Islam Universitas Islam Indonesia;

Indrayana, Deny. "Konpleksitas Peraturan Daerah Bernuansa Syari'at Perspektif Hukum Tata Negara". Yustisia Jurnal Hukum. Edisi 81 September-Desember 2010. Surakarta: Fakultas Hukum Universitas Sebelas Maret;

Ka'bah, Rifyal.1999. Hukum Islam di Indonesia. Jakarta: Universitas Yasri;

Kusumohamidjoyo, Budiono. "Politik Hukum dan pembangunan Hukum Nasional dalam PJPT II”. Pro Justitia Majalah Hukum. 1993. Bandung: Fakultas Hukum Universitas Padja-jaran;

Lumbun, T. Gayus. "Budaya Hukum Mempengaruhi Pelestarian Lingkungan", Jurnal IImu Hukum "Era Hukum". No. 1 Tahun 11 September 2003. Jakarta: Fakultas Hukum Universitas Tarumanegara;

Mansyur, M. Ali. "Pancasila Sebagai Dasar Pengembangan Ilmu Hukum Indonesia". Jurnal Hukum. Vol. XV No. 1 Juni 2005. Semarang: Fakultas Hukum Unversitas Sul$\tan$ Agung;

Mardani. "Kedudukan Hukum Islam Dalam Sistem Hukum Nasional". Jurnal Hukum. No. 2 Vol. 16 April 2009. Yokyakarta: Fakultas Hukum Universitas Islam Indonesia; 
Maroni. "Problematik Penggantian Hukum-hukum Kolonial dengan Hukum-hukum Nasional sebagai Politik Hukum". Jurnal Dinamika Hukum, Vol. 12 No 1 Januari 2012. Purwokerto: Fakultas Hukum Jenderal Sudirman;

Saby, Yuni. "Pelaksanaan Syari'at Islam di Aceh; Suatu Peluang dan Tantangan". Jurnal Kanun. 2002. Banda Aceh: Fakultas Hukum Universitas Syiah Kuala;

Soemarno, Maleha. "Negara Hukum Indonesia Ditinjau dari Sudut Teori Tujuan Negara". Jurnal Hukum \& Pembangunan. Tahun 37 No. 2 April-Juni 2007. Jakarta: Fakultas Hu-kum Universitas Indonesia;

Surbakti, Natangsa. "Pidana Cambuk Dalam Perspektif Keadilan Hukum dan Hak Asasi Manusia di Provinsi Naggroe Aceh Darussalam". Jurnal Hukum. No. 3 Vol. 17 Juli 2010. Yokyakarta: Fakultas Hukum Universitas Islam Indonesia;

Sutrisno, Endang. "Mengukuhkan Paradigma Hukum di Era orde Reformasi". Jurnal Ilmiah. Edisi 01/Juni/2005. Cirebon: Fakultas Hukum Universitas Swadaya Gunung Jati;

Syaukani, Imam. 2006. Rekontruksi Epistimologi Hukum Islam Indonesia Dan Relevansinya Bagi Pembangunan Hukum Nasional. Jakarta: PT RajaGrasindo Persada;

Yusuf A, Hasanudin. "Sejarah dan Perkembangan Islam di Aceh". Jurnal Ar-Raniry. Edisi No. 82 Tahun 3003. Banda Aceh: Institut Agama Islam Negeri Ar-Raniry;

Z A, Syadli M. "Pendidikan Islam di Kesultanan Aceh: Ulama, Meunasah dan Rangkang". Jurnal al Qalam. Vol. 20 No. 96 Tahun 2003. Banten: Sekolah Tinggi Agama Islam Sultan Maulana Hasanudin. 